\title{
Antibacterial activity, metabolites and elemental analysis of Saussurea candicans C. B. Clarke
}

\author{
M. C. Sidhu', Shweta Puri ${ }^{1 *}$, Avantika Sharma² \\ ${ }^{1}$ Department of Botany, Panjab University, Chandigarh, India, ²Department of Microbial Biotechnology, Panjab University, \\ Chandigarh, India
}

Received: 22.01.2017

Accepted: 06.02.2017

Published: 08.02.2017

*Address for correspondence:

Shweta Puri, Department of

Botany, Panjab University,

Chandigarh, India.

E-mail: purishweta999@

gmail.com

\begin{abstract}
Phytochemical analysis of ethanol and water extracts of Saussurea candicans has indicated the presence of flavonoides, phenolics, tannins, etc., that supports its use in traditional medicine both for human and animals in different parts of the world. $S$. candicans is a plant of medicinal interest hence selected for analysis. Antibacterial activity of the two extracts was tested against Enterococcus faecalis, Escherichia coli, Pseudomonas aeruginosa, and Staphylococcus aureus. Only the ethanol extract was found to be effective. Both aqueous and ethanol extracts were prepared and studied for different phytochemicals such as alkaloids, flavonoides, phenolics, and steroids and also for their antibacterial activity using agar well diffusion method. The Fourier transform infrared and wavelength dispersive X-ray fluorescence spectroscopy of whole plant powder were done to study the functional groups and elemental profile, respectively. The aqueous extract contains more (11) phytochemicals as compared to ethanol (9). No zone of inhibition was observed at different volumes of the extract, i.e., $20 \mu \mathrm{l}, 50 \mu \mathrm{l}$ and $100 \mu \mathrm{l}$ but at $150 \mu \mathrm{l}$, and $200 \mu \mathrm{l}$ concentration of $230.7 \mathrm{mg} / \mathrm{ml}$ plant extracts, the zone of inhibition was reported. The dose of $150 \mu$ l concentration active only against $E$. faecalis, whereas, $200 \mu$ l concentration showed activity against all bacterial strains. Only the ethanol extract had antibacterial activity against all the tested bacteria. The medicinal activity of $S$. candicans is assumed to be because of the presence of different phytochemicals and elements. Further study can be conducted to understand the role of each and every reported phytochemicals and elements.
\end{abstract}

KEY WORDS: Bacterial strains, fourier transform infrared, medicinal value, phytochemicals, Saussurea candicans, wavelength dispersive $\mathrm{X}$-ray fluorescence

\section{INTRODUCTION}

Saussurea DC. is an important genus of the family Asteraceae comprising nearly 410 species out of which 61 of these are growing in India. Saussurea candicans C. B. Clarke (syn. Saussurea heteromalla; accepted name Himalaiella heteromalla [D. Don] Raab-Straube) is an annual, tall, herbaceous plant. It grows profusely in the Shivalik ranges, the foothills of Himalayas extending to higher altitudes of Himalayas from Jammu and Kashmir Eastwards to Arunachal Pradesh (Saklani and Rao, 2000).

The leaves are arranged in a dense basal rosette form having lyrate-pinnatifid basal leaves and upper leaves with white tomentose on abaxial side. Capitulam inflorescence has purple flowers with cottony involucral bracts in 3-5 series. The fruits are achenes; 4-5 angled with muricated surface and possess white pappus (Hajra, 1996). The whole plant or different parts have high ethnomedicinal importance. The seeds have carminative and styptic properties and cooling effect; leaves are useful in the treatment of horse bite (Jain, 1991; Ambasta, 1994; Rana and Samant, 2011; Bhatia et al., 2014; Shedayi et al., 2014). Plant extract is used to cure inflammation, rheumatoid arthritis, cough with cold, stomach-ache, dysmenorrhea, altitude sickness, cancer, bacterial diseases, wounds and fatigue (Ahmad et al., 2009; Bisht and Purohit, 2010; Habiba et al., 2016). In view of its importance in traditional and modern medicines, this study has been undertaken to analyze the antibacterial activity of this species. Efforts have also been made to screen various phytochemicals using different extracts and to study the elemental profile of this plant species. This will help in establishing the relationship between chemical properties of the plant and its curative potential. This investigation is likely be useful for different research groups as there are no such previous reports for this plant to the best of our knowledge and literature. 


\section{MATERIALS AND METHODS}

\section{Collection of Material and Preparation of Extracts}

The plant material (whole plant) was gathered from the campus, Panjab University, Chandigarh. The washing of material was done with running tap and distilled water (DW). A herbarium sheet was prepared from the dried plant specimen. The plant specimens were compared with the herbarium of the Botany Department, Panjab University, Chandigarh, and deposited in the herbarium (PAN No. 20330). The powder was made from a dried material with the help of electric grinder and kept in a polythene bags. The extracts were prepared as follows:

\section{Aqueous extract}

Plant powder (20 g) was mixed into $100 \mathrm{ml}$ DW taken in a conical flask and kept for $24 \mathrm{~h}$ on orbital shaker. The mixture was filtered through muslin cloth and then through Whatmann's No. 1 filter paper. The extract was added to vials and kept in the refrigerator at $4{ }^{\circ} \mathrm{C}$ until further use (Gupta et al., 1996). The extract was $200 \mathrm{mg} / \mathrm{ml}$ in concentration.

\section{Ethanol extract}

The ethanol extract of powdered plant material was prepared using the Soxhlet apparatus (Yadav and Agarwala, 2011). $10 \mathrm{~g}$ powder was extracted with $130 \mathrm{ml}$ of ethanol at $60^{\circ} \mathrm{C}$. The extract was evaporated to its $1 / 3^{\text {rd }}$ volume at room temperature and stored in vials at $4{ }^{\circ} \mathrm{C}$.

\section{Phytochemical Screening}

Screening of phytochemicals both in aqueous and ethanol extracts of $S$. candicans was done following the procedure of the previous studies (Sidhu and Sharma, 2016; Thakur and Sidhu, 2013).

\section{Antibacterial Assay}

\section{Bacterial strains}

The plant extracts will be studied for their activity against following bacteria:

\begin{tabular}{ll}
\hline Gram-positive bacteria & Enterococcus faecalis (MTCC 439) \\
& Staphylococcus aureus (ATCC 25923) \\
Gram-negative bacteria & Escherichia coli (ATCC 25922) \\
& Pseudomonas aeruginosa (ATCC 27853) \\
\hline
\end{tabular}

\section{Inoculum Preparation}

From a streak plate, a single colony of bacterial strain was inoculated in $10 \mathrm{ml}$ Mueller Hinton Broth (MHB) media (g/L: Beef infusion 300, casein acid hydrolysate
17.5, starch 1.5, and $\mathrm{pH} 7.4 \pm 0.1)$ in the tubes. These tubes were incubated for $16-18 \mathrm{~h}$ at $37^{\circ} \mathrm{C} / 200 \mathrm{rpm}$. This is a primary culture. Now, $100 \mu \mathrm{l}$ of primary culture was inoculated into $10 \mathrm{ml}$ MHB media. The tubes were incubated at $37^{\circ} \mathrm{C} / 200 \mathrm{rpm}$ for $16-18 \mathrm{~h}$ until absorbance reaches 0.3 at $600 \mathrm{~nm}$.

\section{Bacterial Susceptibility Test}

The antibacterial activity of extracts was studied through agar well diffusion method. The zone of inhibition if any was measured (diameter in millimeter around the well). $100 \mu \mathrm{l}$ of culture was spread on Mueller-Hinton agar plates and allowed to dry. A sterile cork borer was used to make wells in agar media. Sterile water and ethanol were used as a control. The sterile discs were filled aseptically with the different volumes of the extract, i.e., $20 \mu \mathrm{l}$, $50 \mu \mathrm{l}$, and $100 \mu \mathrm{l}$ initially and plates were then kept at $37^{\circ} \mathrm{C} /$ overnight. Inhibition zone was checked after $24 \mathrm{~h}$. If no zone of inhibition was observed, the experiment was repeated and this time each well was loaded with $150 \mu \mathrm{l}$ and $200 \mu \mathrm{l}$ concentration of $230.7 \mathrm{mg} / \mathrm{ml}$ plant extracts. Further, the time interval was also increased for $48 \mathrm{~h}$. It has been noted that activity of the extracts remained similar to $24 \mathrm{~h}$. However, contamination has been observed in some cases near $48 \mathrm{~h}$.

Fourier transform infrared (FTIR) spectroscopy for functional groups has been done using Perkin Elmer Spectrum 400 FTIR/FTFIR spectrometer and wavelength dispersive X-ray fluorescence (WD-XRF) analysis for elemental detail was carried out at Sophisticated Analytical Instrumentation Facility, CIL and UCIM, Panjab University, Chandigarh.

\section{RESULTS AND DISCUSSION}

\section{Phytochemical Study}

Phytochemical screening of both (aqueous and ethanol extract) of whole plant powder of $S$. candicans has been done. Various phytochemicals reported during the analysis were presented in Table 1. The phytoconstituents such as gums and mucilages, phlobatannins, and saponins were not present in ethanol extract. The number of different phytochemicals obtained in ethanol extract was lesser as compared to aqueous extract but in higher concentration (Table 1). The ethanol is efficient in the cell wall and seed degradation thus supposes to release more chemical compound from the material under investigation (Lapornik et al., 2005). Previously quantitative analysis of flavonoides carried out in the ether extract of $S$. heteromalla and recorded the amount of flavonoids as $3.9 \pm 1.0 \%$ 
in the extract (Yaseen et al., 2014). However, the pharmacologically importance of arctigenin, arctiin and chlorojanerin of this species were examined (Saklani et al., 2011). Arctigenin and arctiin were known to be anti-inflammatory whereas, chlorojanerin possess antiulcer and antiviral properties. Both the extracts were studied for their antibacterial activity against four bacteria during the present investigation (Table 1).

\section{Antibacterial Activity}

The extracts showed inhibitory activity against bacterial isolates Enterococcus faecalis (MTCC 439), Escherichia coli (ATCC 25922), Pseudomonas aeruginosa (ATCC 27853), and Staphylococcus aureus (ATCC 25923) (Figure 1a-d). In this study, E. coli, P. aeruginosa, and $S$. aureus strains have shown resistance against $S$. candicans ethanol extract at $34.605 \mathrm{mg} / \mathrm{ml}$ conc. A $4 \mathrm{~mm}$ zone of inhibition was observed against E. faecalis (Figure 1a.6A). However, a dose of $46.2 \mathrm{mg} / \mathrm{ml}$ ethanol extract has formed $11 \mathrm{~mm}, 9 \mathrm{~mm}, 8 \mathrm{~mm}$, and $5 \mathrm{~mm}$ inhibition zones against P. aeruginosa, S. aureus, E. coli, and E. faecalis, respectively, (Figure 1c6,d6,b6 and a6B). This study on antibacterial activity of $S$. candicans is likely to be the first. The anti-inflammatory activity of Saussurea heteromalla was due to the presence of chlorojanerin (a guaianolide type of sesquiterpene lactone) (Saklani et al., 2012).

The size of zone of inhibition is related to the dose and concentration of the ethanol extract (Figure 1). The inhibition zone ranges between 4 and $11 \mathrm{~mm}$ (Figure 2). All the tested bacterial strains were resistant to different doses of aqueous extract. The minimum inhibitory concentration was varied from $4.620 \mathrm{mg} / \mathrm{ml}$ to $46.200 \mathrm{mg} / \mu \mathrm{l}$.

Table 1: Phytoconstituents screening in two extracts of Saussurea. candicans

\begin{tabular}{llcc}
\hline Phytochemical(s) & Test(s) & \multicolumn{2}{c}{ S. candicans } \\
\cline { 2 - 4 } & & Aqueous & Ethanol \\
\hline Alkaloids & Mayer's reagent test & + & + \\
Carbohydrates & Molisch test & +++ & +++ \\
Flavonoids & $\mathrm{NaOH}$ test & + & ++ \\
& $\mathrm{H}_{2} \mathrm{SO}_{4}$ test & + & ++ \\
Glycosides & $\mathrm{FeCl}_{3}$ test & +++ & +++ \\
Gums and mucilages & - & ++ & - \\
Phenolics & - & +++ & + \\
Phlobotannins & - & +++ & - \\
Reducing sugar & - & +++ & ++ \\
Saponins & $\mathrm{Froth} \mathrm{test}_{\text {Steroids }}$ & ++ & - \\
Tannins & $\mathrm{H}_{2} \mathrm{SO}_{4}$ test & ++ & +++ \\
& $\mathrm{FeCl}_{3}$ test & ++ & +++ \\
Terpenoids & $\mathrm{KOH}$ test & - & ++ \\
\hline
\end{tabular}

Symbols: - (absent) $;+$ (present) $;++$ (moderately present); +++ (present in abundance)
The extracts have shown lesser activity for Gram-negative bacteria. This difference is likely due to variations in the structure of cell wall of bacterial strains. However, during this study, maximum inhibitory activity of the $S$. candicans has been reported against $P$. aeruginosa, Gram-negative bacteria.

\section{FTIR}

The FTIR spectra have provided the detail of various functional groups depending on the peak values. Accordingly, these spectra are considered as a "fingerprinting tool." The FTIR spectrum of S. candicans has confirmed the presence of different phytochemicals (Figure 3). The functional groups reported for this species have been examined with the available literature (Pavia et al., 2006).

The researchers had applied FTIR spectroscopy as a tool to study the functional groups present in the powder

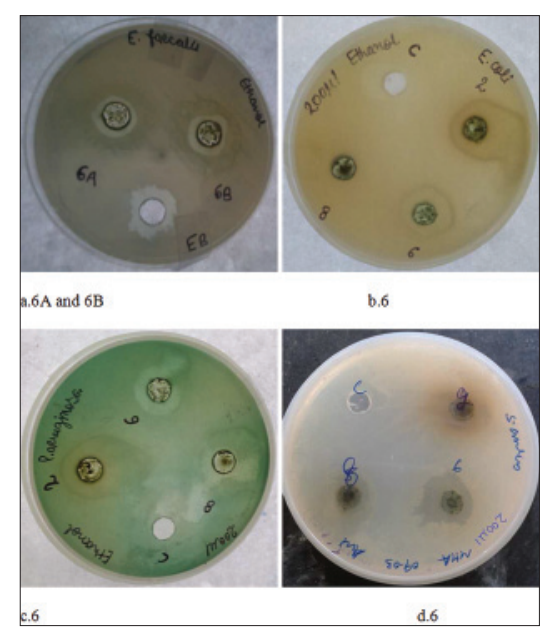

Figure 1: Antibacterial activity of Saussurea candicans whole plant extract. (a) Enterococcus faecalis (4 mm, $5 \mathrm{~mm}$ ) (b) Escherichia coli $(8 \mathrm{~mm}),(\mathrm{c})$ Pseudomonas aeruginosa $(11 \mathrm{~mm})$, and (d) Staphylococcus aureus $(9 \mathrm{~mm})$

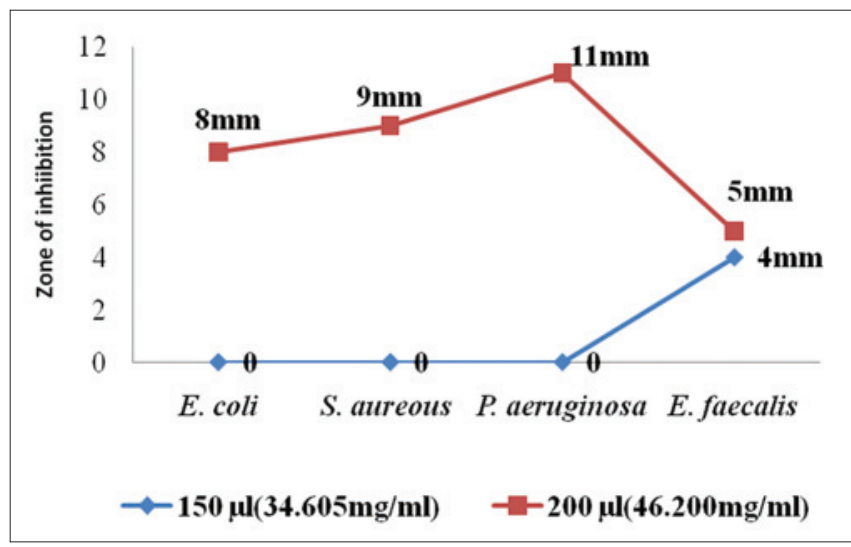

Figure 2: Antibacterial activity 
for classification and differentiation between closely related plants and other organisms (Janakiraman et al., 2011; Thenmozhi et al., 2011). Similarly, this study on S. candicans has produced novel pharmacognostical and phytochemical markers (Table 2). However, further detailed studies would help to examine the chemistry of each and every chemical compounds.

\section{WD-XRF Spectroscopy}

In addition to this, elements such as $\mathrm{Al}, \mathrm{Ca}, \mathrm{Cr}, \mathrm{Cu}, \mathrm{Fe}$, $\mathrm{Hg}, \mathrm{Mg}, \mathrm{Ni}, \mathrm{Si}, \mathrm{Ti}$, and $\mathrm{Zn}$ were also known to inhibit the growth of E. coli, S. aureus, and some other bacteria (Niira et al., 1990; Sawai, 2003; Tsuang et al., 2008; Hetrick et al., 2009; Baek and An, 2011; and Ravikumar et al., 2012). Whereas, the inhibitory activity of elements such as $\mathrm{S}, \mathrm{Cl}, \mathrm{Cu}$, and $\mathrm{Zn}$ against $E$. faecalis were also reported (Wright et al., 1998; Aarestrup and Hasman, 2004). Alkaloids and flavonoids were found responsible for antibacterial activity (Phillipson and O'Neill, 1987; Tsuchiya et al., 1996). These findings also supported by other researchers (Ogbulie et al., 2007). According to them, antibacterial activity against $S$. aureus was due to alkaloids, flavonoids, and tannins. Screened alkaloids, flavonoids, saponins, tannins, and terpenoids of the leaf

Table 2: FTIR spectroscopy of $S$. candicans

\begin{tabular}{|c|c|c|}
\hline Mode of vibration (functionality) & Range & IR frequencies \\
\hline $\mathrm{N}-\mathrm{H}$ stretch in amines & $3500-3300 / \mathrm{cm}$ & $3279 / \mathrm{cm}$ \\
\hline $\mathrm{N}$-H stretch in amides & $3500-3180 / \mathrm{cm}$ & \\
\hline Alkanes $\mathrm{sp}^{3} \mathrm{C}-\mathrm{H}$ stretch & $3000-2840 / \mathrm{cm}$ & $2917 / \mathrm{cm}$ \\
\hline $\begin{array}{l}\mathrm{C}=0 \text { stretch in carboxylic acids, } \\
\text { esters, aldehydes, ketones, Anhydrides } \\
\text { and acid chlorides }\end{array}$ & $1750-1700 / \mathrm{cm}$ & $1732 / \mathrm{cm}$ \\
\hline $\mathrm{C}=\mathrm{C}$ stretch & $1600 / \mathrm{cm}$ & $1604 / \mathrm{cm}$ \\
\hline $\mathrm{C}=0$ stretch in amides & $1680-1630 / \mathrm{cm}$ & \\
\hline $\mathrm{N}-\mathrm{H}$ bend in $1^{\circ}$ amines & $1640-1560 / \mathrm{cm}$ & \\
\hline$-\mathrm{CH}_{2}$ bend in alkanes & $1465 / \mathrm{cm}$ & $1429 / \mathrm{cm}$ \\
\hline $\mathrm{C}=\mathrm{C}$ stretch & $1475 / \mathrm{cm}$ & \\
\hline $0-\mathrm{H}$ bend in carboxylic acids & $1440-1400 / \mathrm{cm}$ & \\
\hline C-F stretch & $1400-1000 / \mathrm{cm}$ & $1370 / \mathrm{cm}$ \\
\hline$-\mathrm{CH}_{3}$ bend in alkanes & $1375 / \mathrm{cm}$ & \\
\hline Nitro group has a strong absorption & $1390-1300 / \mathrm{cm}$ & \\
\hline C-N stretch in amines & $1350-1000 / \mathrm{cm}$ & $1315 / \mathrm{cm}$ \\
\hline $\begin{array}{l}\text { Asymmetric } \mathrm{S}=0 \text { stretch in } \\
\text { sulfones, sulfonyl chlorides, sulfates, } \\
\text { sulfonamides }\end{array}$ & $1350-1140 / \mathrm{cm}$ & \\
\hline $\begin{array}{l}\mathrm{C}=0 \text { bending in ketones appears as a } \\
\text { medium intensity peak }\end{array}$ & $1300-1100 / \mathrm{cm}$ & $1238 / \mathrm{cm}$ \\
\hline $\begin{array}{l}\text { Phenyl alkyl ethers give two strong } \\
\text { bonds }\end{array}$ & $1250-1040 / \mathrm{cm}$ & \\
\hline $\begin{array}{l}\text { C-0 stretch in alcohols, ethers, esters, } \\
\text { carboxylic acids, anhydrides }\end{array}$ & $1300-1000 / \mathrm{cm}$ & \\
\hline C-N stretch in amines & $1350-1000 / \mathrm{cm}$ & \\
\hline Aryl fluorides absorb & $1250 / \mathrm{cm}$ & \\
\hline C-N stretch in amines & $1350-1000 / \mathrm{cm}$ & $1027 / \mathrm{cm}$ \\
\hline C-0 stretch in alcohols, ethers, esters & $1260-1000 / \mathrm{cm}$ & \\
\hline $\mathrm{S}=0$ symmetric stretch, strong & $1150 / \mathrm{cm}$ & \\
\hline C-X for bromides/iodide & $<667 / \mathrm{cm}$ & 534 and $406 / \mathrm{cm}$ \\
\hline
\end{tabular}

FTIR: Fourier transform infrared, S. candicans: Saussurea candicans extracts of Erythrophleum africanum were active against P. aeruginosa (Mohammed et al., 2014). All these phytochemicals are reported in the presently studied species and seems to be responsible for antibacterial activity. WD-XRF spectroscopy has provided data related to various macro and micro elements (Figure 4 and Table 3).

Zinc was also recorded in H. heteromalla (Sajad et al., 2016). Earlier reports have suggested the role of different elements against bacteria. Therefore, these are believed to be antibacterial. Thus, it is assumed that antibacterial potential to this plant species may be imparted by the phytochemicals in association with elements.

\section{CONCLUSION}

The ethanol extract of $S$. candicans possess activity against different bacteria under consideration. This species has been designated as an antibacterial based on the activity shown by extracts and quantification of various useful elements. Thus, its medicinal potential especially antibacterial activity of whole plant ethanol extract is

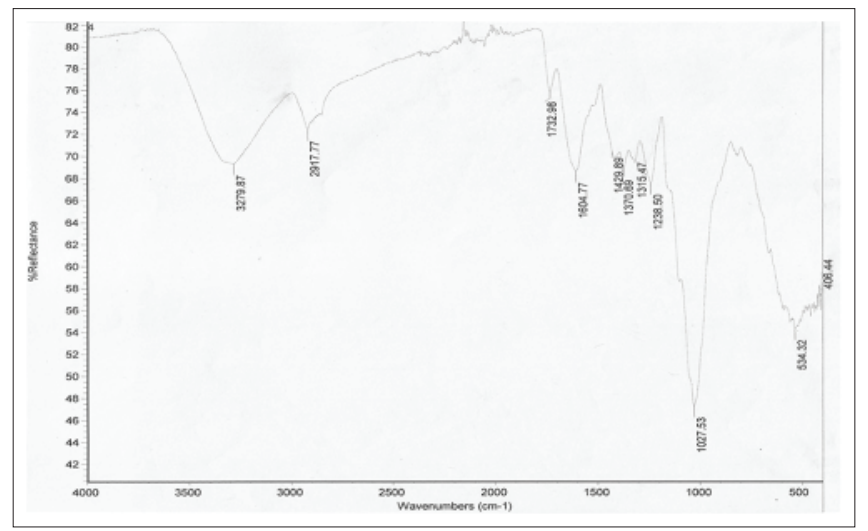

Figure 3: Fourier transform infrared spectrum of whole plant powder of Saussurea candicans

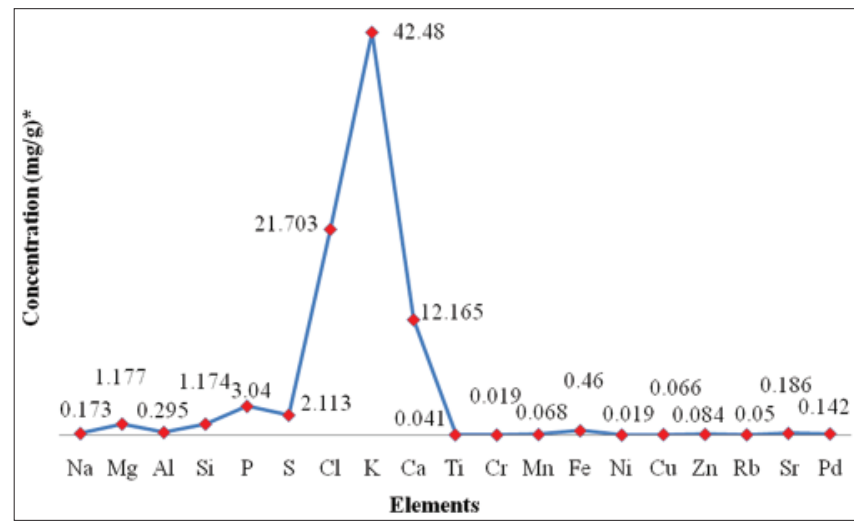

Figure 4: Wavelength dispersive X-ray fluorescence analysis of Saussurea candicans 
Table 3: Elemental analysis of $S$. candicans (Concentration in $\mathrm{mg} / \mathrm{g}$ )*

\begin{tabular}{lclc}
\hline Elements & Concentration & Elements & Concentration \\
\hline $\mathrm{Na}$ & 0.173 & $\mathrm{Cr}$ & 0.019 \\
$\mathrm{Mg}$ & 1.177 & $\mathrm{Mn}$ & 0.068 \\
$\mathrm{Al}$ & 0.295 & $\mathrm{Fe}$ & 0.46 \\
$\mathrm{Si}$ & 1.174 & $\mathrm{Ni}$ & 0.019 \\
$\mathrm{P}$ & 3.040 & $\mathrm{Cu}$ & 0.066 \\
$\mathrm{~S}$ & 2.113 & $\mathrm{Zn}$ & 0.084 \\
$\mathrm{Cl}$ & 21.703 & $\mathrm{Rb}$ & 0.05 \\
$\mathrm{~K}$ & 42.480 & $\mathrm{Sr}$ & 0.186 \\
$\mathrm{Ca}$ & 12.165 & $\mathrm{Pd}$ & 0.142 \\
$\mathrm{Ti}$ & 0.041 & & \\
*The error in concentration values of the elements ranges from $\sim 5 \%$ up
\end{tabular}

to $10 \%$. S. candicans: Saussurea candicans

likely to be because of the presence of phytochemicals and elements. Further investigation is required to understand the role of individual and specific phytoconstituents and elements. To the best of our knowledge and available literature, this study seems to be pioneer in terms of phytochemical, antibacterial, FTIR, andWD-XRF analysis of $S$. candicans.

\section{ACKNOWLEDGMENTS}

We are thankful to the Chairperson, Department of Botany, Panjab University, Chandigarh, for providing the necessary facilities to carry out this research work. Authors are also thankful to the Panjab University, Chandigarh for financial aid out of DST-Purse grant.

\section{REFERENCES}

Aarestrup FM, Hasman H. Susceptibility of different bacterial species isolated from food animals to copper sulphate, zinc chloride and antimicrobial substances used for disinfection. Vet Microbiol 2004;100:83-9.

Ahmad SS, Muhammad F, Dogar ZU, Khan ZI, Ahmad K, Sher MD, et al. Prioritization of medicinal plants of Margala Hills National Park, Islamabad on the basis of available information. Pak J Bot 2009;41:2105-14.

Ambasta SP. The Useful Plants of India. New Delhi, India: Publications and Information Directorate, CSIR; 1994. p. 553.

BaekYW, AnYJ. Microbial toxicity of metal oxide nanoparticles ( $\mathrm{CuO}, \mathrm{NiO}, \mathrm{ZnO}$, and $\mathrm{Sb} 2 \mathrm{O} 3)$ to Escherichia coli, Bacillus subtilis, and Streptococcus aureus. Sci Total Environ 2011;409:1603-8.

Bhatia H, Sharma YP, Manhas RK, Kumar K. Ethnomedicinal plants used by the villagers of district Udhampur, J\&K, India. J Ethnopharmacol 2014;151:1005-18.

Bisht VK, Purohit V. Medicinal and aromatic plants diversity of Asteraceae in Uttarakhand. Nat Sci 2010;8:121-8.

Gupta VP, Govindaiah, Datta RK. Plant extracts: A non- chemical approach to control Fusarium diseases of mulberry. Curr Sci 1996;71:406-9.

Habiba U, Ahmad M, Shinwari S, Sultana S, Shinwari ZK, Zafar MD. Antibacterial and antifungal potential of Himalayan medicinal plants for treating wound infections. Pak J Bot 2016;48:371-5.

Hajra PK. Brahmkamal and its Allies (Saussurea, the Genus). Dehradun, India: Jugal Kishore and Co.; 1996. p. 102.

Hetrick EM, Shin JH, Paul HS, Schoenfisch MH. Anti-biofilm efficacy of nitric oxide-releasing silica nanoparticles. Biomaterials 2009;30:2782-9.

Jain SK. Dictionary of Indian Folk Medicines and Ethnobotany. Vol. XVIII. New Delhi, India: Deep Publications; 1991. p. 311.

Janakiraman N, Sathish SS, Johnson M. UV-VIS and FT-IR spectroscopic studies on Peristrophe bicalyculata (Retz.) Nees. Asian J Pharm Clin Res 2011;4:125-9.

Lapornik B, Prosek M, Wondra AG. Comparision of extracts prepared from plant by-products using different solvents and extraction time. J Food Eng 2005;71:214-22.

Mohammed M, Musa AM, Garba MA, Adeiza AA, Hanwa UA. Phytochemical and antimicrobial study on the leaf extracts of Erythrophleum africanum (Caesalpiniaceae). Afr J Biotechnol 2014;13:598-603.

Niira R, Yamamoto T, Uchida M. Antibiotic Zeolite. US Patent 4938958 A; 1990.

Ogbulie JN, Ogueke CC, Okoli IC, Anyanwu BN. Antibacterial activities and toxicological potentials of crude ethanolic extracts of Euphorbia hirta. Afr J Biotechnol 2007;6:1544-8.

Pavia DL, Lampman GM, Kriz GS. Introduction to Spectroscopy. $3^{\text {rd }}$ ed. India: Thomson Business Information India Private Limited; 2006.

Phillipson JD, O'Neill MJ. New leads to the treatment of protozoal infections based on natural product molecules. Acta Pharm Nord 1987;1:131-44.

Rana MS, Samant SS. Diversity, indigenous uses and conservation status of medicinal plants in Manali wildlife sanctuary, North Western Himalaya. Indian JTradit Knowl 2011;10:439-59.

Ravikumar S, Gokulakrishnan R, Boomi P. In vitro antibacterial activity of the metal oxide nanoparticles against urinary tract infectious bacterial pathogens. Asian Pac J Trop Dis 2012;2:85-9.

Sajad MA, Khan MS, Naeem A, Ali H. Screening of plants for the phytoremediation of zinc from Dir Lower, Khyber Pakhunkhwa, Pakistan. J Biodivers Environ Sci 2016;8:206-18.

Saklani A, Hegde B, Mishra P, Singh R, Mendon M, Chakrabarty D, et al. NF-KB dependent anti-inflammatory activity of chlorojanerin isolated from Saussurea heteromalla. Phytomedicine 2012;19:988-97.

Saklani A, Rao RR. In: Pangtey YP, editor. High Altitudes of the Himalayas - II, Biodiversity, Ecology \& Environment. 
$2^{\text {nd }}$ ed. Nainital, India: Gyanodaya Prakashan; 2000. p. 323.

Saklani A, Sahoo MR, Mishra PD, Vishwakarma R. Saussurea heteromalla (D. Don) hand - Mazz: A new source of arctiin, arctigenin and chlorojanerin. Indian $\mathrm{J}$ Chem 2011;50B:624-6.

Sawai J. Quantitative evaluation of antibacterial activities of metallic oxide powders $(\mathrm{ZnO}, \mathrm{MgO}$ and $\mathrm{CaO})$ by conductimetric assay. J Microbiol Methods 2003;54:177-82.

Shedayi AA, Xu M, Gulraiz B. Traditional medicinal uses of plants in Gilgit-Baltistan, Pakistan. J Med Plant Res 2014;8:992-1004.

Sidhu MC, SharmaT. Meiotic and phytochemical studies of three morphotypes of Solanum nigrum L. from Punjab (India). Indian Drugs 2016;53:20-8.

Thakur S, Sidhu MC. Phytochemical screening of leaves and seeds of Magnolia grandiflora L. Der Pharm Lett 2013;5:278-82.

Thenmozhi M, Bhavya PK, Sivaraj R. Compounds identification using HPLC and FT-IR in Eclipta alba and Emilia sonchifolia. Int J Eng Sci Technol 2011;3:292-8.

TsuangYH, Sun JS, Huang YC, Lu CH, Chang WH, Wang CC. Studies of photokilling of bacteria using titanium dioxide nanoparticles. Artif Organs 2008;32:167-74.

Tsuchiya H, Sato MT, Miyazaki S, Fujiwara S, Tanigaki M, Ohyama T, et al. Comparative study on the antibacterial activity of cariogenic bacteria in vitro by plant flavanones. Experientia 1996;50:846-9.

Wright JB, Lam K, Burrell RE. Wound management in an era of increasing bacterial antibiotic resistance: A role for topical silver treatment. Am J Infect Control 1998;26:572-7.

Yadav RN, Agarwala M. Phytochemical analysis of some medicinal plants. J Phytol 2011;3:10-4.

Yaseen MD, Irshad N, Hussain I, KamalY. Quantitative analysis of flavonoid contents in ether extract of different medicinal plants naturally growing in Pakistan. Indian J Adv Plant Res 2014;1:34-6. 